\title{
Factors Affecting the Intention of the Rice Farmers to Adopt the Integrated Cash Waqf Environmental Protection Model: An Empirical Study in Kedah Malaysia*
}

\author{
Rafia AFROZ ${ }^{1}$, Md. MUHIBBULLAH ${ }^{2}$, Mohammed Niaz MORSHED ${ }^{3}$
}

Received: June 27, 2019 Revised: September 16, 2019 Accepted: September 24, 2019

\begin{abstract}
The objectives of this study are to propose the Integrated Waqf Environmental Protection Model (IWEP) and investigate the farmers' intention to adopt it. In developing the IWEP model and investigating farmers' willingness to adopt it, this study surveyed 400 farmers in Kedah. The intention of the farmers to adopt the proposed model was analysed by adding perceived barriers and socioeconomic variables into the theory of reasoned action (TRA) model. The collected data were processed using structural equation modelling (SEM). The SEM results show that the subjective norm is positive and has a significant impact on the intentions of lowincome farmers to accept the IWEP model. This indicates that the decision of the low-income farmers to accept the IWEP model is significantly influenced by their family members, neighbours and friends. Furthermore, awareness and perceived barriers have a greater impact on the elderly, highly educated and wealthy farmers. The findings indicate that the elderly, highly educated and wealthy farmers are aware of climate change and they perceive higher risks or barriers to climate change. As a result, they are more likely to have an adaptation intention. If we encourage people to create waqf fund, we can increase the value of the farmer and the country's total GDP.
\end{abstract}

Keywords : Waqf, Climate Change, Adaptation, Planned Behaviour, Structural Equation Modelling

JEL Classification Code : D2, D7, G4, Q2, Q5

\section{Introduction}

Malaysia's agricultural sector has incurred huge losses

* The authors would like to acknowledge the P-RIGS (funding of "Digital development, Economics Growth. Environmental Sustainability and Population Health in Malaysia: Applying Response Surfaces for the F-test of cointegration model" (Ref no: P-RIGS18-006-006).

1 First Author and Corresponding Author, Department of Economics, Faculty of Economics and Management Sciences, International Islamic University Malaysia, Malaysia. [Postal Address: 53100, Jalan Gombak, Kuala Lumpur, Malaysia]

Email: rafia@iium.edu.my

2 Department of Economics, Faculty of Economics and Management Sciences, International Islamic University Malaysia, Malaysia. Email: muhibedu@gmail.com

3 Department of Finance, Faculty of Economics and Management Sciences, International Islamic University Malaysia, Malaysia. Email: tanbirbiu45@gmail.com

(c) Copyright: Korean Distribution Science Association (KODISA) This is an Open Access article distributed under the terms of the Creative Commons Attribution Non-Commercial License (http://Creativecommons.org/licenses/by-nc/4.0/) which permits unrestricted noncommercial use, distribution, and reproduction in any medium, provided the original work is properly cited. due to flooding. UNISDR (2011) reported that in the flood incident of December 2006, losses were estimated to an amount of USD 18.8 million involving 6,797 farmers and 8,322 hectares of arable land. Alleviating these loses, the government spent 2.6 million dollars in financial aid to farmers. In the December 2007 floods, estimated losses were approximately USD 18.5 million, of which the government covered $46 \%$. Spending on flood control is becoming a burden to the government. The Muda Agriculture Development Area (MADA) is located in Kedah and is considered the largest producer of rice in Malaysia. It represents $40 \%$ of the total rice production in Malaysia (MADA, 2009). Since 1988, MADA areas have experienced six major floods, five of which occurred between 2003 and 2008, showing an increasing trend in floods (Department of Agriculture, 2009). The damages to rice farmers in the MADA area were estimated at an average of 5.5 tonnes per hectare, and the value of the damaged was estimated at 13.8 million dollars. To date, the worst flood disaster occurred in 2005 , in which 19,185 hectares (20\% of the surface of the MADA) were affected (Department of Agriculture, 2009). 
Thus, this study proposes an integrated cash waqf environmental protection (IWEP) model as an alternative solution for the farmers to withstand and adapt to changes in the climate. Next, this study investigates farmers' intention to adopt the proposed model using the primary data collected from the survey administered to rice farmers in Kedah, Malaysia. Before conducting the survey, a focus group survey was conducted to gather the opinions and recommendations of experts from waqf institutions, MADA and the Faculty of Economics and Management Sciences, International Islamic University Malaysia on the suitability, applicability and prospects of the proposed model. The details of the focus group are not discussed in this article.

This article is divided into nine parts comprising an (1) introduction; (2) literature review focusing on the use of waqf in environmental protection and agricultural development; (3) Discussion on the proposed IWEP model; (4) Farmers' Intention to Adopt the IWEP Model and Hypothesis Development; (5) Research Methods; (6) Data analysis and Results; (7) Conclusion; (8) implication for farmers; and (9) Future research.

\section{Use of Waqf in Environmental Protection and Agricultural Development}

Waqf can be defined as an act of dedicating an asset and appropriating its benefits for a specific use. This action makes it impossible to alienate a waqf asset and transfer its ownership (Sadeq, 2002). Waqf can be applied to perishable objects. The benefit can be obtained without using the property itself (Rahaman, Fahmi, \& Faisol, 2011). The assignment of a waqf refers to the intention by which the waqif (donor) made a waqf, and it may be general or specific. The waqif or the donor refers to the person or parties that contribute to the waqf fund. He has a right to specify how the property should be invested and the intended use of the waqf's benefit (Nuruddeen, 2010). The conditions that the waqif has imposed on the property should be upheld and respected. The waqif may also determine the way the waqf is managed and the process of succession of the managers or the mutawalli (Ahmed, 2007).

The mutawalli is often the term used to describe the manager of the accumulated waqf funds. The mutawalli is normally responsible for administering the waqf properties to ensure it serves the best interest of the mawquf 'alayh or the beneficiaries. The mutawalli has many responsibilities, but the most pressing task is to preserve the property and maximise the potential revenues in the interest of the mawquf alayh. The mutawalli can either perform the role with compensation or, in some cases, do so voluntarily (Kahf, 2003). Several underlying contracts can be used to manage the cash waqf disbursement such as:
a) Mudharabah (Profit-sharing)
b) Musharakah (Partnership)

Mudharabah or the profit-sharing includes two parties entering into a contract where a party will provide the capital, and the other will provide their skills and effort. The party who provides the capital will be termed the rabb al$\mathrm{mal}$, and the party who provides the entrepreneurial skill is termed the mudharib. In the event of profit, it is disbursed between the rabb al-mal and mudharib according to the predetermined profit-sharing ratio agreed by both parties. In the case of loss, it is absorbed solely by the rabb al-mal (Usman \& Rahman, 2015).

Musharakah, on the other hand, is a form of profitsharing where two or more parties may jointly contribute the capital and manage the business. Profit-sharing, unlike the mudharabah contract, is shared according to the capital contribution ratio of each partner. Loss in the musharakah contract is also treated similar to the profit distribution according to the capital contributed (Usman \& Rahman, 2015).

\section{Proposed Integrated Waqf Model}

The proposed IWEP model aims to integrate the cash waqf directly to assist farmers facing barriers to adapting to climate change. Figure 1 shows how the IWEP model will operate. In this model, it is assumed that public and corporate donors will contribute cash to the CWI with the intention to create a perpetual waqf. The corporate sector may donate as a part of their corporate social responsibility (CSR). The public may also contribute cash voluntarily. The techniques in the cash waqf model can be used to raise funds. It requires diverse techniques because different waqifs (donor) prefer different ways of cash waqf endowment.

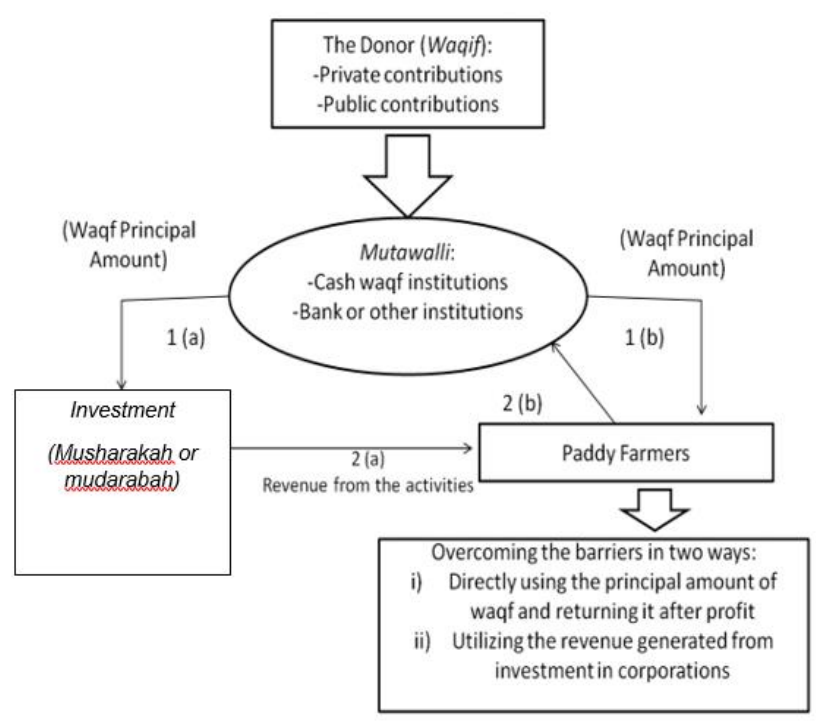

Figure 1: The IWEP system flow model (authors illustration)

To encourage people to dedicate property for a charitable purpose, the Malaysian government has provided a tax 
incentive for donations, including cash waqf in section 44(6) the Income Tax Act 1967 (Reference no. LHDN.01/35/42/51/179-6.5621 Government Gazette No. 14369 dated 27.07.2004) (www.mais.gov.my; Hasan \& Abdullah, 2008). The donors will then become the waqif, and the CWI will act as the mutawalli which manages the fund and is responsible for making the necessary investment decisions of the waqf fund which will generate revenue. The farmers will be the targeted beneficiaries (mawquf 'alayh) in this waqf model. The mutawalli may invest the funds in any Shariah-compliant corporation using a mudharabah and musharakah contract as shown by 1 (a) in Figure 1. The generated revenue will then be distributed to the farmers or used to overcome farmers' hardships as shown by 2 (a) in Figure 1. The financial assistance is to assist farmers so they can continue cultivating their farm for the next season, in the case of natural disasters. The assistance may include purchasing new varieties of seed and other equipment that requires financing.

Similarly, the mutawalli may directly give a proportion of the principal amount to the farmers as a loan based on qard hassan as shown by 1 (b) in Figure 1. Once the respective farmers generate profit, the principal amount of the waqf is to be returned to the mutawalli with no due date and without interest. This is how the perpetuity concept is implemented, as shown in [2 (b)] in Figure 1. The funds disbursed can then be utilised by either the farmers directly or by CWI as the mutawalli to provide the necessary facilities for farmers to overcome the challenges they face. The suggested aids are matched against the type of hardships or barriers.

\section{Farmers' Intention to Adopt the IWEP Model and Hypothesis Development}

Figure 2 presents the theoretical framework of this study.

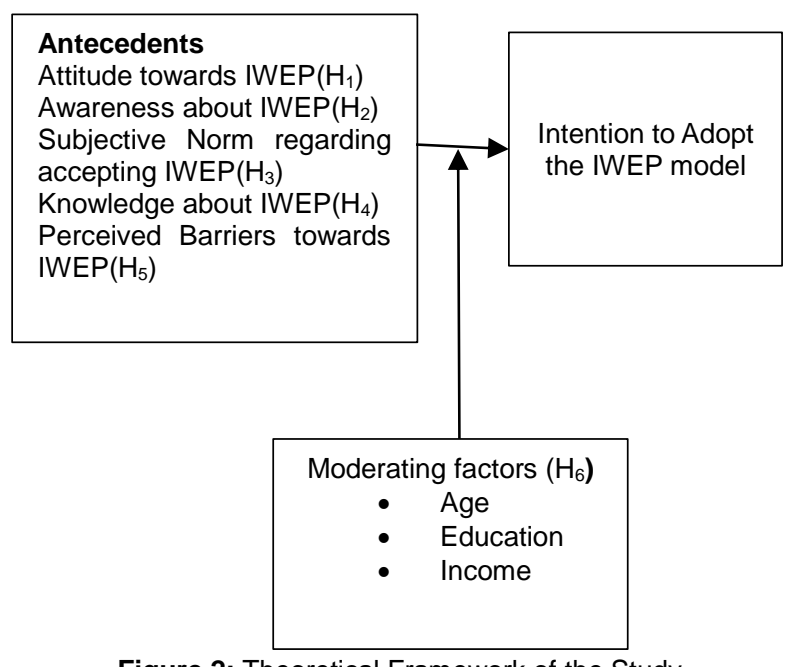

Figure 2: Theoretical Framework of the Study
It shows the relationship between the individual-level antecedents (attitude, awareness, subjective norm, knowledge, perceived barriers) and intention of the farmers to adopt the IWEP model. It also shows the moderating effect of socio-economic variables on the intention of the farmers to adopt the IWEP model.

\subsection{Impact of Attitude, Awareness and Subjective Norm on Farmer's Intention to Adopt the IWEP Model}

Attitude refers to when a person favours or disfavours an object, person or event (Ajzen, 2005). It may reflect the overall judgement of the behaviour performed by the person (de Groot, Daran-Lapujade, van Breukelen, Knijnenburg, de Hulster, Reinders, \& Slijper, 2007; Fishbein \& Ajzen, 1980). If a farmer finds that by using special technology or method will result in reducing vulnerability to climatic risks and increases yield, he is more likely to accept it. In the context of this study, we argue that the farmers are expected to have a positive attitude and utilise IWEP model because it will help them overcome the challenges they may face to climate change. In contrast, they may feel the impact of climate change on the quantity and quality of crop production, but for religious reasons, they are reluctant to attribute it to climate change. Sometimes, they do not want to accept any donation and prefer to depend solely on their earnings.

Furthermore, awareness results from the role of information quality and learning, which enables a person to be conscious of something that happens. The fact that if farmers are aware of the existence of government assistance programs and their awareness increases their participation rate in the said programs. Hence, we propose our first and second hypothesis as follows:

H1: Attitude towards the IWEP model will have a positive, direct effect on the farmer's intention to adopt the IWEP model.

H2: Awareness of the farmers towards IWEP model will have a positive, direct effect on the farmer's intention to adopt the IWEP model.

On the other hand, subjective norm which is another construct of TRA model, is defined as the feeling that a specific person who matters approves or disapproves of a given behaviour (Ajzen, 2005). This independent variable is equally important since the farmers' decision can be ascertained by the approval or aversion of those close to them. If the people close to the farmers approve of the idea that the IWEP model will be beneficial and should be used, it can change the farmers' attitude and willingness to accept the model. The same is true if the people close to the farmers believed that accepting the IWEP is not beneficial, it is likely that the farmers will not adopt it (Chang, 1998; Fishbein \& Ajzen, 1975). So, based on the argument, we propose the third hypothesis as follows: 
H3: Subjective norm will have a positive, direct effect on the farmer's intention to adopt the IWEP model.

\subsection{Impact of Knowledge on Farmer's Intention to Adopt the IWEP Model}

Apart from attitude and subjective norm, another important variable is the knowledge and expertise of the farmers concerning the adaptation methods suggested by the climate change policy. Experience, guidance and awareness are the leading determinants of the farmers' level of knowledge. Farmers with more experience will have a higher capability to set a strategy that matches the labour supply, farm equipment and farm income. For instance, if a farm is experiencing a high cost of labour, the farmer will choose to be involved in a least-costly method or technology. So, we propose our fourth hypothesis as follows:

H4: Knowledge of the farmers about IWEP model will have a positive, direct effect on the farmer's intention to adopt the IWEP model.

\subsection{Impact of Perceived Barriers on Farmer's Intention to Adopt the IWEP Model}

Perceived barriers relate to voluntary psychological blocks or components that may impede positive action. This means that whenever a person is going to improve the environment, he may face various barriers such as economic and social barriers. Antwi, Dougill, and Stringer (2013) states that the most common financial barriers are a budget deficit or lack of funds for adaptation. This is due to the fact that each adaptation process entails direct or indirect financial costs, and farmers, as a rule, are the part of the society that are considered low-income and has a limited amount of credit. This leads to difficulties in implementing adaptation measures; such as the acquisition of new varieties of seeds that are less vulnerable to climate, the inability to acquire the necessary tools and equipment, the inability to withstand irrigation costs due to uneven distribution of precipitation. Sometimes farmers do not have enough knowledge about climate change, which increases their inability to recognise the changes, the threat they pose, and ways to overcome it. If their perception of barriers is positive, they intend to adopt the IWEP model because they will believe that the IWEP model will help them overcome the barriers that they currently face.

So, we develop the fifth hypothesis as follows:

H5: Perceived barriers will have a positive, direct effect on the farmer's intention to adopt the IWEP model.

\subsection{IntentSocial Demographic Factors}

The demographic factors of the farmer can also influence the rate of participation and acceptance in an adaptation policy model. Vanslembrouck, Huylenbroeck, and Verbeke (2002) state that the age, gender, education level and farm size can influence the decision to accept the model suggested for adaptation to climate change. Based on the above discussions, the following hypotheses were formulated:

H6: Age, education and income will moderate the relationships between individual-level antecedents (attitudes, awareness, subjective norm, knowledge and perceived barriers) and the intention to adopt the IWEP model.

\section{Research Method}

\subsection{Location of the Study}

The study was conducted among farmers in the Muda District Agricultural Development Authority (MADA) in Kedah, Malaysia. MADA is in the Muda Irrigation System, which is composed of approximately 125,155 hectares of land, of which 105,851 hectares are in the northwest division of the State of Kedah, and 20,304 hectares are in the southern region of the State of Perlis. Kedah contributes around $50 \%$ of Malaysia's rice production. Kedah is Malaysia's eighth largest state. Figure 3 shows the map of MADA in Kedah.

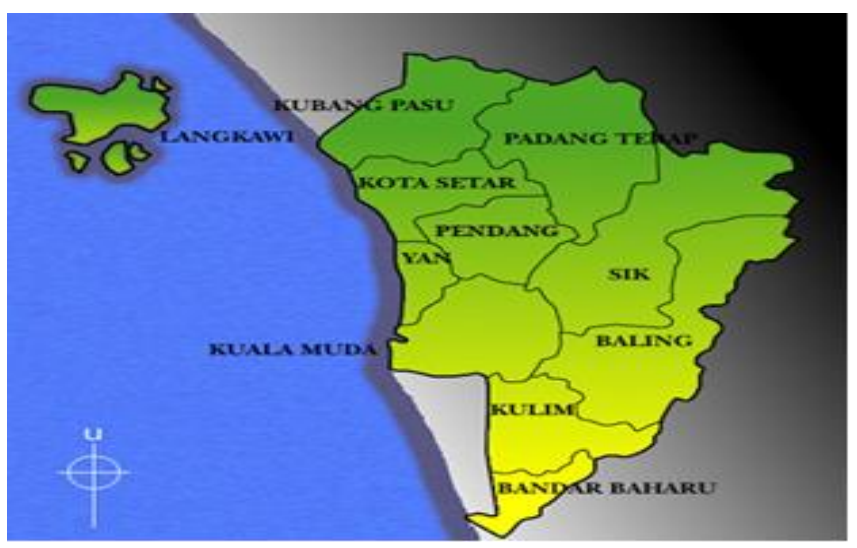

Figure 3: The Map of Kedah

\subsection{Sampling and Sample Size}

This study used a stratified simple random sampling technique. The entire study area was stratified into 27 PPK strata, based on the homogenous group with approximately 55,000 farmers. Due to time and budget constraint, seven strata (7 PPK) was selected using simple random sampling. Simple random sampling has an equal chance to be selected in the sample. A total of 350 respondents from the 7 PPK was selected for this study. 


\subsection{Procedure}

Questionnaires were hand-distributed to 350 respondents in the study area. Being hand-delivered will enable the researchers to clarify any issues. The aim of the research was explained to the respondents. After two weeks, the completed questionnaires were collected. A total of 300 questionnaires were completed and usable for further analysis. This indicates a response rate of $85 \%$.

\subsection{Instruments}

The items in the theoretical framework of this study were adopted from the established literature (Gonzalez \& Silveira, 1997; Dimitrakopoulos, Jones, Iosifides, Florokapi, Lasda, Paliouras, \& Evangelinos, 2010; Hoehn \& Thapa, 2009; Masud, Akhtar, Afroz, Al-Amin, \& Kari, 2015; Masud, Rahman, Al-Amin, Kari, \& Leal Filho, 2014; Hedlund-de, Witt, De Boer, \& Boersema, 2014) and were included in the questionnaire. The respondents were asked to respond to each question using a five-point Likert scale which ranges from 1- strongly disagree to 5- strongly agree. The questionnaire has two sections. The first section asked about the respondents' socioeconomic information while the second section asked about their attitude, subjective norm, awareness, knowledge, perceived barriers and intention to adopt the proposed model. The items of the instruments have been shown in Table 1 in the Appendix.

\section{Data Analysis and Results}

\subsection{The Sociodemographic Characteristics of the Respondents}

Respondents of this study consisted of $92.7 \%$ male and $7.3 \%$ female. Majority of the respondents are male farmers. This is because Malaysian agriculture is dominated by male farmers. Their ages ranged between 50 to 65 years with $80.3 \%$ while those aged 46 to 50 years were $17 \%$. It seems that most of the rice farmers in the study area are aged above 45 years. This is because young people do not like to do agricultural production. Youths' interest in the agricultural sector is decreasing over the years. Furthermore, 35\% of those working in the agricultural sector has low productivity, and most of them are small-scale farmers and the elderly. Youths are part of a farming family, but many rural parents in developing countries do not want their children to farm. Without parental support, it is not easy for young people to get involved in family farming (Ridha \& Wahyu, 2017; Widiyanti, Setyowati, \& Ardianto, 2018). 91.3\% of respondents had formal education including primary education $(32.7 \%)$, lower secondary education $(31.3 \%)$, and higher secondary education $(27.3 \%)$, diploma $(0.3 \%)$ while $8.3 \%$ had no formal education. Most of the participants have a monthly income of less than RM 2000 (60.7\%), 35\% of the participants' income was between RM2001 and RM4000, $4 \%$ of the respondents' incomes were between RM4001 and RM6000. Only one $(0.3 \%)$ farmer had a monthly income ranging from RM6001 to RM8000. This indicates that Malaysian farmers are relatively poor. According to the Department of Statistics Malaysia, more than half of Malaysian households earn a monthly income of less than RM3,000. The remaining households earn between RM3,001 and RM4,000 (12.9\%), RM4,001 and RM 5,000 (8.6\%), RM5,001 and RM10,000 (15.8\%) and above RM10,000 (4.9\%) (DOSM, 2009).

\subsection{Result of the Correlation Analysis}

Prior to SEM analysis, the descriptive statistics (mean and standard deviation) and the correlation among the variables of the study were analysed. The correlation matrix shows that all predictive variables correlate significantly positively with the intention of farmers to adopt the suggested model.

\subsection{Measurement Model}

A measurement model was estimated using maximum likelihood estimation. The 30 initial elements developed for the measurement were submitted to CFA. Next, after running the new measurement models, the results of CFA with 24 items (after the items eliminated and correlated) showed the fitness of the data, as shown in Figure 4. The chi-square value $\left(\lambda^{2}\right)$ of the measurement model was $318.459(\mathrm{df}=236, \mathrm{p}=0.000)$. The normed $\lambda^{2}$ value of 1.349 fell within a range below 5 as suggested by Marsh and Hocevar (1985). Other measures showed that the measurement model fits well with the data (RMSEA $=.030$, CFI = 0.902). Consequently, this measurement model was used for all subsequent analyses. Meanwhile, as shown in Table 1 , construct reliability (CR) values were well above the 0.70 level suggested by Nunnally (1978). All standardised factor loadings emerged as being fairly high and significant, ranging from 0.609 to 0.953 . This result suggested that there was a convergence of the indicators with the appropriate underlying factors (Anderson \& Gerbing, 1988). The average values of the variance extracted (AVE) for each construct were all greater than 0.50 (Fornell \& Larcker, 1981). In general, these results showed strong evidence of the unidimensionality, reliability and validity of the measures. Later, the discriminant validity was examined. Smith (1996) suggested that the AVE of each construct should be compared with its squared correlation (SC) with other constructs. In this sense, if the AVE of a factor is greater than the SC between that and any other factor, the factor exhibits discriminant validity. Based on Table 2, the result showed that the square root of the AVE between each pair of factors was greater than the estimated SC among the factors, which confirms its discriminant validity (Hair, Black, Babin, Anderson, \& Tatham, 2006). 
Table 1: The CFA results for the measurement model

\begin{tabular}{|c|c|c|c|c|c|}
\hline Construct & Item & $\begin{array}{l}\text { Factor } \\
\text { loading }\end{array}$ & $\begin{array}{c}\text { Cronbach's } \\
\text { alpha } \\
\text { (above0.7) }\end{array}$ & $\begin{array}{c}\text { CR } \\
\text { (above } \\
0.7) \\
\end{array}$ & $\begin{array}{c}\text { AVE } \\
\text { (above } \\
0.5) \\
\end{array}$ \\
\hline \multirow{4}{*}{$\begin{array}{l}\text { Attitude } \\
\text { (ATT) }\end{array}$} & Att1 & 0.838 & \multirow{4}{*}{0.926} & \multirow{4}{*}{0.930} & \multirow{4}{*}{0.768} \\
\hline & Att2 & 0.879 & & & \\
\hline & Att3 & 0.917 & & & \\
\hline & Att4 & 0.869 & & & \\
\hline \multirow{4}{*}{$\begin{array}{l}\text { Awareness } \\
\text { (AW) }\end{array}$} & AW1 & 0.759 & \multirow{4}{*}{0.928} & \multirow{4}{*}{0.830} & \multirow{4}{*}{0.549} \\
\hline & AW2 & 0.764 & & & \\
\hline & AW3 & 0.718 & & & \\
\hline & AW4 & 0.729 & & & \\
\hline \multirow{3}{*}{$\begin{array}{l}\text { Subjective } \\
\text { Norm (SN) }\end{array}$} & SN1 & 0.857 & \multirow{3}{*}{0.913} & \multirow{3}{*}{0.835} & \multirow{3}{*}{0.629} \\
\hline & SN2 & 0.765 & & & \\
\hline & SN3 & 0.754 & & & \\
\hline \multirow{4}{*}{$\begin{array}{l}\text { Knowledge } \\
(\mathrm{KN})\end{array}$} & KN1 & 0.609 & \multirow{4}{*}{0.923} & \multirow{4}{*}{0.834} & \multirow{4}{*}{0.559} \\
\hline & KN3 & 0.764 & & & \\
\hline & KN4 & 0.798 & & & \\
\hline & KN5 & 0.804 & & & \\
\hline \multirow{5}{*}{$\begin{array}{l}\text { Intention } \\
\text { (INT) }\end{array}$} & IN1 & 0.838 & \multirow{5}{*}{0.928} & \multirow{5}{*}{0.950} & \multirow{5}{*}{0.791} \\
\hline & IN2 & 0.896 & & & \\
\hline & IN3 & 0.927 & & & \\
\hline & IN4 & 0.953 & & & \\
\hline & IN5 & 0.826 & & & \\
\hline \multirow{4}{*}{$\begin{array}{l}\text { Perceived } \\
\text { Barriers } \\
\text { (PB) }\end{array}$} & PB1 & 0.902 & \multirow{4}{*}{0.913} & \multirow{4}{*}{0.919} & \multirow{4}{*}{0.741} \\
\hline & PB2 & 0.878 & & & \\
\hline & PB3 & 0.789 & & & \\
\hline & PB4 & 0.869 & & & \\
\hline
\end{tabular}

Table 2: Inter-construct correlation and SC

\begin{tabular}{|c|c|c|c|c|}
\hline PB & ATT & SN & AW & INT \\
\hline $\mathbf{0 . 8 6 1}$ & & & & \\
\hline 0.237 & $\mathbf{0 . 8 7 6}$ & & & \\
\hline 0.663 & 0.223 & $\mathbf{0 . 7 9 3}$ & & \\
\hline 0.166 & 0.481 & 0.263 & $\mathbf{0 . 7 4 1}$ & \\
\hline 0.556 & 0.234 & 0.580 & 0.295 & $\mathbf{0 . 8 8 9}$ \\
\hline
\end{tabular}

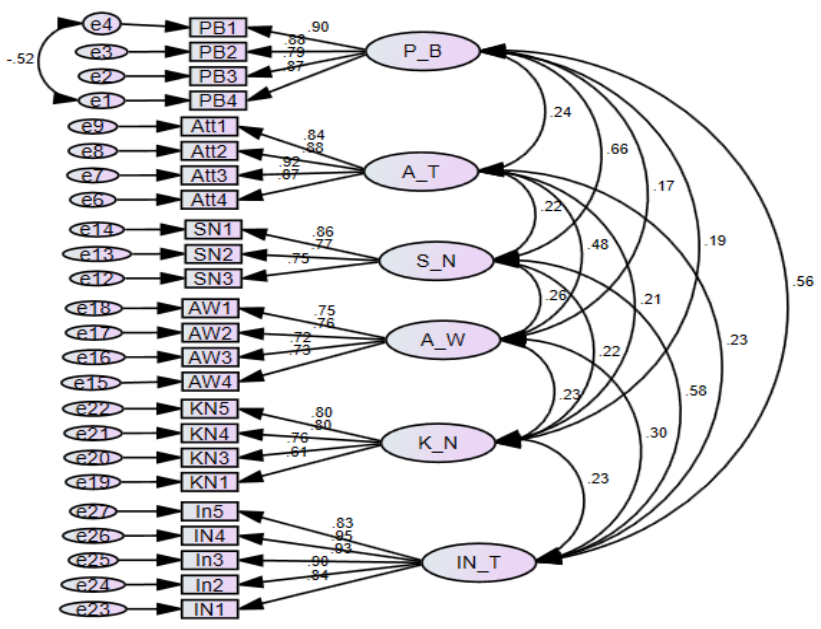

Figure 4: Final measurement model

\subsection{Discussion and Implication}

A structural model was estimated to investigate the hypotheses of the study. The goodness-of-fit statistics of the proposed model showed that the model reasonably fitted the present data. The chi-square value of the model $\left(\lambda^{2}=353.24\right.$, $\mathrm{df}=244, \mathrm{p}=0.000)$ and other goodness-of-fit indices (normed $\lambda^{2}=1.449 ;$ RMSEA $=0.089 ; \mathrm{CFI}=0.869$ ) revealed that the model fit the data reasonably well. The structural results of the proposed model are depicted in Figure 3. The path coefficients of the structural model have been measured to assess the statistical significance of the path coefficients (please see Table 6). The results of the structural model show that awareness, subjective norm and perceived barriers significantly affects the intention of the farmers to adopt the proposed model. The results of the SEM revealed that the path coefficient of attitude is 0.017 , but statistically insignificant which is inconsistent with $\mathrm{H}_{1}$. It means that there is a lack of awareness about the benefits of this model. This result is consistent with Läpple and Kelley (2010), and Hattam (2006) who also found that attitude had an insignificant influence on the intention to convert to organic agriculture.

Table 3: The result $\rightarrow$ s of the structural model

\begin{tabular}{|c|c|c|c|c|c|}
\hline $\begin{array}{c}\text { Hypo- } \\
\text { thesis }\end{array}$ & $\begin{array}{c}\text { Relation- } \\
\text { ship }\end{array}$ & Beta & $\begin{array}{c}\mathbf{t} \\
\text { value }\end{array}$ & $\begin{array}{c}\mathbf{p} \\
\text { value }\end{array}$ & Decision \\
\hline H1 & ATT $\rightarrow$ INT & 0.017 & 0.431 & 0.666 & $\begin{array}{c}\text { Not } \\
\text { supported }\end{array}$ \\
\hline H2 & AW $\rightarrow$ INT & 0.129 & 2.614 & 0.009 & Supported \\
\hline H3 & SN $\rightarrow$ INT & 0.326 & 4.287 & 0.000 & Supported \\
\hline H4 & KN $\rightarrow$ INT & 0.094 & 0.605 & 0.108 & $\begin{array}{c}\text { Not } \\
\text { supported }\end{array}$ \\
\hline H5 & PB $\rightarrow$ INT & 0.277 & 4.517 & 0.000 & supported \\
\hline
\end{tabular}

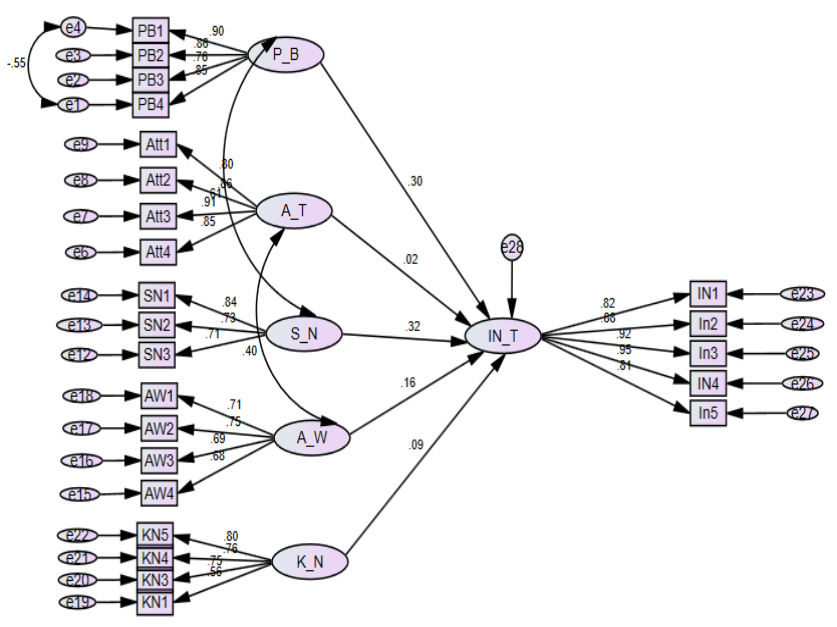

Figure 5: Structural model

Awareness of climate change problems stimulates environmental concern, which in turn motivates farmers to engage in adaptation behaviours or practices (Kollmuss \& Agyeman, 2002). The results show that the coefficient of awareness is 0.129 which is positively and significantly related with the intention to adopt the proposed model, accepting $\mathrm{H}_{2}$. Awareness of climate change is playing a vital role to influence farmers to make the appropriate decision for adaptation behaviour (Roque, 2011). Many studies found 
a positive relationship between awareness, attitudes and behaviour (Shoukry, Saad, Eltemsahi, \& Abolfotouh, 2012; Lillemo, Alfnes, Halvorsen, \& Wik, 2013; Masud et al., 2014).

Additionally, the subjective norm is 0.326 which is positively and significantly related with the intention to adopt the proposed model, which supports $\mathrm{H}_{3}$ and reflects that the people around the farmers are accepting the model and encouraging them to adopt the proposed model. Attitudes, subjective norms and perceived control were found to positively influence farmers' intentions to use rice variety innovations in India (Yamano, Rajendran, \& Malabayabas, 2015), to use improved grassland management practices in Brazil and Mexico (Borges, Lansink, Ribeiro, \& Lutke, 2014; Martínez-García, Dorward, \& Rehman, 2013), to manage riparian and water-zone areas sustainably in Australia (Fielding, Terry, Masser, Bordia, \& Hogg, 2005), and to adopt sustainable practices in paddy production in Malaysia (Terano, Mohamed, Shamsudin, \& Latif, 2015).

The path coefficient for knowledge is 0.094 which is positive but statistically not significant, and it does not support $\mathrm{H}_{4}$. These results reveal that knowledge can increase or, in some cases, diminish the perceptions of risk and, therefore, indirectly relate to environmental behaviours. Alternatively, increases in knowledge can directly affect environmental behaviours.

Finally, the path factor for perceived barriers is 0.277 , which is positive and statistically significant and supports H5. This indicates that perceptions of risk and knowledge increase people's willingness to take action to solve environmental problems. However, risk perception and knowledge share a scenario with common environmental perceptions and demographic characteristics. Despite interconnections, perceptions of risk, knowledge, and shared environmental beliefs are independent predictors of behavioural intentions (O’Connor, Bord, \& Fisher, 1999). This conclusion is also consistent with the findings of Bayard and Jolly (2007), who found a significant relationship between these variables. For example, if a person has a feeling of deterioration of the environment, this feeling can lead to more significant change in attitude. This change will help them form a favourable attitude towards environmental behaviour.

To test the categorical moderation hypotheses, the critical ratios for the differences in regression weights between groups of age (young, old), education (primary and no formal education, higher secondary) and income (low, medium) were produced. From these critical ratios, the pvalues were calculated to determine the significance of the differences. The results are summarised in the hypotheses summary Table 4, Table 5 and Table 6 below.
Table 4: Multi-Group Moderating effects for age (H6: Age will moderate the relationships between individual-level antecedents (attitudes, awareness, subjective norm, knowledge and perceived barriers) and the intention to adopt IWEP model)

\begin{tabular}{|c|c|c|c|c|c|}
\hline \multirow{2}{*}{$\begin{array}{c}\text { Hypo- } \\
\text { thesis }\end{array}$} & $\begin{array}{c}\text { Relation- } \\
\text { ship }\end{array}$ & $\begin{array}{c}\text { Below } \\
\mathbf{2 5} \\
\text { years } \\
\text { old }\end{array}$ & $\begin{array}{c}\mathbf{5 0} \text { to } 65 \\
\text { years } \\
\text { old }\end{array}$ & \% Diff & Results \\
\hline $\mathrm{H}_{1}$ & ATT $\rightarrow$ INT & 0.034 & -0.001 & 3.3 & $\begin{array}{c}\text { Both } \\
\text { insig }\end{array}$ \\
\hline $\mathrm{H}_{2}$ & $\mathrm{AW} \rightarrow$ INT & 0.255 & 0.503 & -24.8 & Both sig \\
\hline $\mathrm{H}_{3}$ & $\mathrm{SN} \rightarrow$ INT & 0.161 & 0.086 & 7.5 & $\begin{array}{c}\text { Both } \\
\text { insig }\end{array}$ \\
\hline $\mathrm{H}_{4}$ & $\mathrm{KN} \rightarrow$ INT & 0.093 & 0.122 & -2.9 & $\begin{array}{c}\text { Both } \\
\text { insig }\end{array}$ \\
\hline $\mathrm{H}_{5}$ & $\mathrm{~PB} \rightarrow \mathrm{INT}$ & 0.293 & 0.342 & -4.9 & Both sig \\
\hline
\end{tabular}

Table 5: Multi-Group Moderating effects for education (H6: Education will moderate the relationships between individual-level antecedents (attitudes, awareness, subjective norm, knowledge and perceived barriers) and the intention to adopt IWEP model)

\begin{tabular}{|c|c|c|c|c|c|}
\hline \multirow[b]{2}{*}{$\begin{array}{l}\text { Hypo- } \\
\text { thesis }\end{array}$} & \multirow[b]{2}{*}{$\begin{array}{l}\text { Relation- } \\
\text { ship }\end{array}$} & \multicolumn{2}{|c|}{ Beta } & \multirow[b]{2}{*}{$\%$ Diff } & \multirow[b]{2}{*}{ Results } \\
\hline & & $\begin{array}{l}\text { Low } \\
\text { educa- } \\
\text { tion }\end{array}$ & $\begin{array}{l}\text { High } \\
\text { educa- } \\
\text { tion }\end{array}$ & & \\
\hline $\mathrm{H}_{1}$ & ATT $\rightarrow$ INT & 0.078 & 0.002 & 7.6 & $\begin{array}{l}\text { Both } \\
\text { insig }\end{array}$ \\
\hline $\mathrm{H}_{2}$ & $\mathrm{AW} \rightarrow \mathrm{INT}$ & -0.011 & 0.233 & -22.2 & $\begin{array}{l}\text { Sig for } \\
\text { higher } \\
\text { educati } \\
\text { on }\end{array}$ \\
\hline $\mathrm{H}_{3}$ & $\mathrm{SN} \rightarrow \mathrm{INT}$ & 0.067 & 0.138 & -7.1 & $\begin{array}{l}\text { Both } \\
\text { insig }\end{array}$ \\
\hline $\mathrm{H}_{4}$ & $\mathrm{KN} \rightarrow \mathrm{INT}$ & 0.06 & 0.065 & -0.5 & $\begin{array}{l}\text { Both } \\
\text { insig }\end{array}$ \\
\hline $\mathrm{H}_{5}$ & $\mathrm{~PB} \rightarrow \mathrm{INT}$ & 0.106 & 0.311 & -20.5 & $\begin{array}{l}\text { Sig for } \\
\text { higher } \\
\text { educati } \\
\text { on }\end{array}$ \\
\hline
\end{tabular}

Table 6: Multi-Group Moderating effects for income (H6: Income will moderate the relationships between individual-level antecedents (attitudes, awareness, subjective norm, knowledge and perceived barriers) and the intention to adopt IWEP model)

\begin{tabular}{|c|c|c|c|c|c|}
\hline \multirow{2}{*}{$\begin{array}{l}\text { Hypo- } \\
\text { thesis }\end{array}$} & \multirow{2}{*}{$\begin{array}{l}\text { Relation- } \\
\text { ship }\end{array}$} & \multicolumn{2}{|c|}{ Beta } & \multirow{2}{*}{$\begin{array}{c}\% \\
\text { Diff }\end{array}$} & \multirow[b]{2}{*}{ Results } \\
\hline & & $\begin{array}{c}\text { Low } \\
\text { income }\end{array}$ & $\begin{array}{l}\text { Medium } \\
\text { income }\end{array}$ & & \\
\hline $\mathrm{H}_{1}$ & $\mathrm{ATT} \rightarrow \mathrm{INT}$ & -0.031 & 0.083 & -5.2 & $\begin{array}{l}\text { Both } \\
\text { insig }\end{array}$ \\
\hline $\mathrm{H}_{2}$ & $\mathrm{AW} \rightarrow \mathrm{INT}$ & 0.357 & 0.245 & 11.2 & $\begin{array}{c}\text { Both } \\
\text { sig }\end{array}$ \\
\hline $\mathrm{H}_{3}$ & $\mathrm{SN} \rightarrow \mathrm{INT}$ & 0.192 & -0.040 & 15.2 & $\begin{array}{l}\text { Sig for } \\
\text { low } \\
\text { income }\end{array}$ \\
\hline $\mathrm{H}_{4}$ & $\mathrm{KN} \rightarrow \mathrm{INT}$ & 0.078 & 0.059 & 1.9 & $\begin{array}{l}\text { Both } \\
\text { insig }\end{array}$ \\
\hline $\mathrm{H}_{5}$ & $\mathrm{~PB} \rightarrow \mathrm{INT}$ & 0.267 & 0.252 & 1.5 & $\begin{array}{l}\text { Both } \\
\text { sig }\end{array}$ \\
\hline
\end{tabular}

Table 4 shows the multi-group effects for the youth (below 25 years) and older adults (aged 50 to 65 years). Attitude, subjective norm and knowledge have an insignificant effect while awareness and perceived barriers 
have a significant effect on both young and old farmers. Awareness and perceived barriers have a stronger effect on the intention to adopt the proposed model for old farmers. The results present a significant difference between young and old age ranging from $-24.8 \%$ to $7.5 \%$. This is inconsistent with other studies demonstrating that older farmers tend to adopt technological innovations in their farming practices (Shiferaw \& Holden, 1998; Maddison, 2006; Ishaya \& Abaje, 2008).

Table 5 shows the multi-group effects of low education (primary education) and high education (> secondary education) groups. The results indicate that awareness and intention to adopt the proposed model has a significant relationship in the higher education group with a path coefficient of 0.233 . This indicates that education increases the awareness of the farmers regarding the proposed model. Similar results were found in the case of perceived barriers with a path coefficient of 0.311. Also, the percentage difference in path coefficient from perceived barriers to intention to adopt the proposed model is $-20.5 \%$. It means that the perceived barriers have much more significant effects on intention in the higher education group compared to the low education group. This is consistent with Norris and Batie (1987), who found that education encourages Virginia farmers to accept improved technologies. Supporting this finding, in Nigeria (Igodan, Ohaji, \& Ekpere, 1988) and China (Lin, 1991), education positively affects the adoption of improved technologies. Education was found to increase the probability of taking adaptive measures such as soil conservation and changing planting dates (Deressa, Hassan, Ringler, Alemu, \& Yesuf, 2009; Glendinning, Mahapatra, \& Mitchell, 2001; Dolisca, Carter, McDaniel, Shannon, \& Jolly, 2006; Anley, Bogale, \& Haile-Gabriel, 2007; Deressa et al., 2009).

Table 6 presents the multi-group moderating effects for low-income (RM 2,000 and less than 2000) and mediumincome (2000-4000) groups. Awareness has a significant impact on the intention for both income groups. However, the impact in the low-income group is $11.2 \%$ higher than the high-income group. Similar results appear between perceived barriers and intention with a small percentage difference of $1.5 \%$ in the low-income group than the highincome group. These results moderating the effects for income indicate that awareness and perceived barriers have a much larger effect on intention in the low-income group than the high-income group. Previous studies found that income contributes positively to the adoption of agricultural technologies because higher income allows farmers to adopt measures that are expensive (Franzel, 1999; Knowler \& Bradshaw, 2007; Semenza, Hall, Wilson, Bontempo, Sailor, \& George, 2008). Subjective norm has a significant impact of 0.192 on low-income farmers. This indicates that lowincome farmers are mostly affected by the opinions of the people surrounding them than high-income farmers.

\section{Conclusions}

The research focuses on cash waqf as an alternative source of financial support to farmers. It explored the development of waqf for the benefit of Malaysian farmers. Empirically, the study explored the intentions of the farmers to accept cash waqf to avoid barriers to adaptation, investigating the relationship between the intention of the farmers to accept cash waqf and awareness of cash waqf, attitude towards cash waqf, subjective norms, knowledge and perceived barriers.

From the viewpoint of the experts, the model is considered very useful in providing farmers with financial facilities as it provides an alternative to traditional financial institutions. This model can help the government to reduce expenses on agricultural development. Other Muslim countries could also adopt the proposed model. As a result, this research has contributed to different perspectives. First, it promotes agricultural development in Malaysia by promoting cash to support farmers. Secondly, the research confirms that attitude, awareness, subjective norm, perceived obstacle and knowledge affect the intent to adopt a model to avoid barriers to adaptation. This study found that awareness, subjective norm, and perceived barriers significantly affect farmers' intention to adopt the proposed model. Subjective norm was positive and had a significant impact on the intention of the farmers in the low-income group. This indicates that the decision of the low-income farmers to accept the IWEP model is significantly influenced by their family members, neighbours and friends.

Moreover, this study demonstrates that awareness and perceived barriers have more influence on older farmers, highly educated and wealthy farmers. It is suggested that the government can disseminate information through activities such as conferences, seminars or talk shows on television to increase the awareness of young and less educated farmers about the possible risk and impact of climate change. These activities may also increase the knowledge of farmers about the ability of farmers to mitigate barriers to adaptation to climate change. Third, the research was able to adopt and adapt relevant literature (measurement items) to solve the limited literature in the Malaysian context to develop the theoretical framework. As a result, cash funds are a very powerful institution for fundraising. If we encourage people to directly or indirectly generate cash, we can increase the value of the farmer and the country's total GDP.

\section{References}

Ahmed, H. (2007). Waqf-based microfinance: Realizing the social role of Islamic finance. Paper presented at Integrating Awqaf in the Islamic Financial Sector, Singapore. Retrieved from https://www.isfin.net/sites/isfin.com/files/waqfbased_microfinance- 
_realizing_the_social_role_of_islamic_finance.pdf

Ajzen, I. (2005). Attitudes, personality, and behavior. London, UK: McGraw-Hill Education.

Ajzen, I., \& Fishbein, M. (1980). Understanding attitudes and predicting social behaviour. Upper Saddle River, NJ: Prentice-Hall.

Anderson, J. C., \& Gerbing, D. W. (1988). Structural equation modeling in practice: $\mathrm{A}$ review and recommended two-step approach. Psychological Bulletin, 103(3), 411-423.

Anley, Y., Bogale, A., \& Haile-Gabriel, A. (2007). Adoption decision and use intensity of soil and water conservation measures by smallholder subsistence farmers in Dedo district, Western Ethiopia. Land Degradation \& Development, 18(3), 289-302.

Antwi-Agyei, P., Dougill, A. J., \& Stringer, L. C. (2013). Barriers to climate change adaptation in sub-Saharan Africa: Evidence from northeast Ghana \& systematic literature review (Centre for Climate Change Economics and Policy Working Paper No. 154).

Bayard, B., \& Jolly, C. (2007). Environmental behavior structure and socio-economic conditions of hillside farmers: A multiple-group structural equation modeling approach. Ecological Economics, 62(3-4), 433-440.

Borges, J. A. R., Lansink, A. G. O., Ribeiro, C. M., \& Lutke, V. (2014). Understanding farmers' intention to adopt improved natural grassland using the theory of planned behavior. Livestock Science, 169, 163-174.

Chang, M. K. (1998). Predicting unethical behaviour: A comparison of the theory of reasoned action and the theory of planned behaviour. Journal of Business Ethics, 17, 1825-1834.

de Groot, M. J., Daran-Lapujade, P., van Breukelen, B., Knijnenburg, T. A., de Hulster, E. A., Reinders, M. J., \& Slijper, M. (2007). Quantitative proteomics and transcriptomics of anaerobic and aerobic yeast cultures reveals post-transcriptional regulation of key cellular processes. Microbiology, 153(11), 3864-3878.

Department of Agriculture (2009). Paddy statistics of Malaysia 2007. Putrajaya, Malaysia: Department of Agriculture Peninsular.

Department of Statistics Malaysia (2009). Compendium of environment statistics, Malaysia. Putrajaya, Malaysia: DOSM. Retrieved from www.statistics.gov.my/

Deressa, T. T., Hassan, R. M., Ringler, C., Alemu, T., \& Yesuf, M. (2009). Determinants of farmers' choice of adaptation methods to climate change in the Nile Basin of Ethiopia. Global Environmental Change, 19(2), 248255.

Dimitrakopoulos, P. G., Jones, N., Iosifides, T., Florokapi, I., Lasda, O., Paliouras, F., \& Evangelinos, K. I. (2010). Local attitudes on protected areas: Evidence from three Natura 2000 wetland sites in Greece. Journal of Environmental Management, 91(9), 1847-1854.

Dolisca, F., Carter, D. R., McDaniel, J. M., Shannon, D. A., \& Jolly, C. M. (2006). Factors influencing farmers' participation in forestry management programs: A case study from Haiti. Forest Ecology and Management, 236(2-3), 324-331.

Fielding, K. S., Terry, D. J., Masser, B. M., Bordia, P., \& Hogg, M. A. (2005). Explaining landholders' decisions about riparian zone management: The role of behavioural, normative, and control beliefs. Journal of Environmental Management, 77(1), 12-21.

Fornell, C., \& Larcker, D. F. (1981). Structural equation models with unobservable variables and measurement error: Algebra and statistics. Journal of Marketing Research, 18, 382-388.

Franzel, S. (1999). Socioeconomic factors affecting the adoption potential of improved tree fallows in Africa. Agroforestry Systems, 47(1-3), 305-321.

Glendinning, A., Mahapatra, A., \& Mitchell, C. P. (2001). Modes of communication and effectiveness of agroforestry extension in eastern India. Human Ecology, 29(3), 283-305.

Gonzalez, L. E., \& da Silveira, P. (1997). The people's attitudes towards global environmental phenomena: A case study. Climate Research, 9, 95-100. Retrieved from https://www.int-res.com/articles/cr/9/c009p095.pdf

Hair, J. F., Black, W. C., Babin, B. J., Anderson, R. E., \& Tatham, R. L. (2006). Multivariate data analysis (Vol. 6). Upper Saddle River, NJ: Pearson Prentice Hall.

Hasan, Z., \& Abdullah, M. N. (2008, February). The investment of waqf land as an instrument of Muslims' economic development in Malaysia. In Dubai International Conference on Endowments' Investment (pp. 4-6).

Hattam, C. (2006, August). Adopting organic agriculture: An investigation using the Theory of Planned Behaviour. Paper presented at Intl. Assn of Agr. Econ. Conference (pp. 12-18), Gold Coast, Australia.

Hedlund-de Witt, A., De Boer, J., \& Boersema, J. J. (2014). Exploring inner and outer worlds: A quantitative study of worldviews, environmental attitudes, and sustainable lifestyles. Journal of Environmental Psychology, 37, 4054.

Hoehn, S., \& Thapa, B. (2009). Attitudes and perceptions of indigenous fishermen towards marine resource management in Kuna Yala, Panama. International Journal of Sustainable Development \& World Ecology, 16(6), 427-437.

Igodan, C. O., Ohaji, P. E., \& Ekpere, J. A. (1988). Factors associated with the adoption of recommended practices for maize production in the Kainji Lake Basin of Nigeria. Agricultural Administration and Extension, 29(2), 149-156.

Ishaya, S., \& Abaje, I. B. (2008). Indigenous people's perception on climate change and adaptation strategies in Jema'a local government area of Kaduna State, Nigeria. Journal of Geography and Regional Planning, 1(8), 138-143. Retrieved from https://pdfs.semanticscholar.org/8d8d/55e26d3760b93b6 d63380151f9bf9875d6c8.pdf

Kahf, M. (2003, January). The role of waqf in improving the 
ummah welfare. In International Seminar on Waqf as a Private Legal Body (pp. 6-7).

Knowler, D., \& Bradshaw, B. (2007). Farmers' adoption of conservation agriculture: A review and synthesis of recent research. Food Policy, 32(1), 25-48.

Kollmuss, A., \& Agyeman, J. (2002). Mind the gap: Why do people act environmentally and what are the barriers to pro-environmental behavior? Environmental Education Research, 8(3), 239-260.

Läpple, D., \& Kelley, H. (2013). Understanding the uptake of organic farming: Accounting for heterogeneities among Irish farmers. Ecological Economics, 88, 11-19.

Lillemo, S. C., Alfnes, F., Halvorsen, B., \& Wik, M. (2013). Households' heating investments: The effect of motives and attitudes on choice of equipment. Biomass and Bioenergy, 57, 4-12.

Lin, J. Y. (1991). Education and innovation adoption in agriculture: Evidence from hybrid rice in China. American Journal of Agricultural Economics, 73(3), 713-723.

Maddison, D. (2006). The Perception of and Adaptation to Climate Change in Africa (CEEPA Discussion Paper No. 10). Pretoria, South Africa: Centre for Environmental Economics and Policy in Africa.

Marsh, H. W., \& Hocevar, D. (1985). Application of confirmatory factor analysis to the study of self-concept: First-and higher order factor models and their invariance across groups. Psychological Bulletin, 97(3), 562-582.

Martínez-García, C. G., Dorward, P., \& Rehman, T. (2013). Factors influencing adoption of improved grassland management by small-scale dairy farmers in central Mexico and the implications for future research on smallholder adoption in developing countries. Livestock Science, 152(2), 228-238.

Masud, M. M., Akhtar, R., Afroz, R., Al-Amin, A. Q., \& Kari, F. B. (2015). Pro-environmental behavior and public understanding of climate change. Mitigation and Adaptation Strategies for Global Change, 20(4), 591600.

Masud, M. M., Rahman, M. S., Al-Amin, A. Q., Kari, F., \& Leal Filho, W. (2014). Impact of climate change: An empirical investigation of Malaysian rice production. Mitigation and Adaptation Strategies for Global Change, 19(4), 431-444.

Muda Agricultural Development Authority (MADA) (2011). Reports of flooding and droughts.

Norris, P. E., \& Batie, S. S. (1987). Virginia farmers' soil conservation decisions: An application of Tobit analysis. Journal of Agricultural and Applied Economics, 19(1), 79-90.

Nunnally, J. C. (1978). Psychometric theory (2 $\left.2^{\text {nd }} e d.\right)$. New York, NY: McGraw-Hill

Nuruddeen Muhammad, I. (2010). Scholars, merchants and civil society: Imperative for waqf-based participatory poverty alleviation initiatives in Kano, Nigeria. Humanomics, 26(2), 139-157.

O’Connor R. E., Bord, R. J., \& Fisher, A. (1999). Risk perceptions, general environmental beliefs, and willingness to address climate change. Risk Analysis, 19, 461-471.

Rahaman, M. S., Fahmi, M., \& Faisol, M. (2011). Economics of Cash WAQF management in Malaysia: A proposed Cash WAQF model for practitioners and future researchers. African Journal of Business Management. Retrieved

from http://www.academicjournals.org/article/article13806294 13_Chowdhury\%20et\%20al.pdf

Ridha, R. N., \& Wahyu, B. P. (2017). Entrepreneurship intention in agricultural sector of young generation in Indonesia. Asia Pacific Journal of Innovation and Entrepreneurship, 11(1), 76-89.

Roque, F. S., Jensen, P. B., Schmock, H., Dalgaard, M., Andreatta, M., Hansen, T., \& Jensen, L. J. (2011). Using electronic patient records to discover disease correlations and stratify patient cohorts. PLoS Computational Biology, 7(8), e1002141. https://doi.org/10.1371/journal.pcbi.1002141

Sadeq, A. M. (2002). Waqf, perpetual charity and poverty alleviation. International Journal of Social Economics, 29(1/2), 135-151.

Semenza, J. C., Hall, D. E., Wilson, D. J., Bontempo, B. D., Sailor, D. J., \& George, L. A. (2008). Public perception of climate change: Voluntary mitigation and barriers to behavior change. American Journal of Preventive Medicine, 35(5), 479-487.

Shiferaw, B., \& Holden, S. T. (1998). Resource degradation and adoption of land conservation technologies in the Ethiopian highlands: A case study in Andit Tid, North Shewa. Agricultural Economics, 18(3), 233-247.

Shoukry, S. H., Saad, S. G., Eltemsahi, A. M., \& Abolfotouh, M. A. (2012). Awareness, attitude, and concerns of workers and stakeholders of an environmental organization toward the environment. SAGE Open, 2(4), DOI: $10.1177 / 2158244012462223$.

Smith, R. M. (1996). A comparison of methods for determining dimensionality in Rasch measurement. Structural Equation Modeling: A Multidisciplinary Journal, 3(1), 25-40.

Terano, R., Mohamed, Z., Shamsudin, M. N., \& Latif, I. A. (2015). Factors influencing intention to adopt sustainable agriculture practices among paddy farmers in Kada, Malaysia. Asian Journal of Agricultural Research, 9(5), 268-275.

UNISDR, (2011). Global assessment report on disaster risk reduction. revealing risk, redefining development.

Usman, M., \& Rahman, A. (2015). Financing higher education through Waqf Institution: An alternative approach. Paper presented at Administration and Business Postgraduate Conference on Economics, Public Administration and Business. Kuala Lumpur, Malaysia: Faculty of Economics, University Malaya.

Vanslembrouck, I., Huylenbroeck, G., \& Verbeke, W. (2002). Determinants of the willingness of Belgian farmers to participate in agri-environmental measures. Journal of 
Rafia AFROZ, Md. MUHIBBULLAH, Mohammed Niaz MORSHED / Journal of Asian Finance, Economics and Business Vol 6 No 4 (2019) 189-199

Agricultural Economics, 53(3), 489-511.

Widiyanti, E., Setyowati, N., \& Ardianto, D. T. (2018, November). Young generation's perception on the agricultural sector. Paper presented at IOP Conference Series: Earth and Environmental Science (Vol. 200, No. 1, pp. 12-60). Bristol, United Kingdom: IOP Publishing.
Yamano, T., Rajendran, S., \& Malabayabas, M. L. (2015). Farmers' self-perception toward agricultural technology adoption: Evidence on adoption of submergence-tolerant rice in Eastern India. Journal of Social and Economic Development, 17(2), 260-274. 